Original Research Paper

\title{
The Weight of Seedlings Differs on the Growth of Sargassum sp.
}

\author{
Ifla Afifilah ${ }^{1}$, Nunik Cokrowati ${ }^{1 *}$, Nanda Diniarti ${ }^{1}$ \\ ${ }^{1}$ Program Studi Budidaya Perairan, Fakultas Pertanian Universitas Mataram, Mataram, Indonesia.
}

\author{
Article History \\ Received : February $25^{\text {th }}, 2021$ \\ Revised : March $03^{\text {th }}, 2021$ \\ Accepted : March 08 ${ }^{\text {th }}, 2021$ \\ Published : March 16 ${ }^{\text {th }}, 2021$ \\ *Corresponding Author: \\ Nunik Cokrowati, \\ Program Studi Budidaya \\ Perairan Universitas Mataram, \\ email: \\ nunikcokrowati@unram.ac.id
}

\begin{abstract}
Sargassum sp. is a brown alga containing alginate and iodine and is used in the food, pharmaceutical, cosmetic and textile industries. Cultivation of Sargassum sp. has not been carried out, but it needs efforts to be cultivated so that its availability is sustainable. This study aims to determine the growth of Sargassum sp. cultivated with different seed weight in the longline method. This research was conducted from December 2020 to January 2021, in the waters of Ekas Bay, Ekas Buana Village, Jerowaru District, East Lombok Regency. This research was conducted using experimental methods and using the weight difference treatment of the seeds of Sargassum sp. Cultivation was carried out for 30 days. The experimental design used in this study was a completely randomized design consisting of 5 treatments and 4 replications. The treatments were treatment A (seeds weighing $25 \mathrm{~g}$ ), B (seeds weighing 50 $\mathrm{g}$ ), C (seeds weighing $100 \mathrm{~g}$ as a control), D (seeds weighing $150 \mathrm{~g}$ ) and $\mathrm{E}$ (seeds with a weight of $150 \mathrm{~g}$ ). weight $200 \mathrm{~g}$ ). The results showed that $\mathrm{E}$ treatment showed the best growth results with the growth parameters measured were absolute growth, specific growth, number of leaves and number of fruits. This study concludes that different seed weight has a significant effect on the growth of seaweed Sargassum sp. with the longline method with the best seed weight in this study was the E treatment (200 g) with an absolute growth of $437.5 \mathrm{~g}$, a specific growth rate of $21.50 \%, 4999$ fruit numbers, and 3614 leaves.
\end{abstract}

Keywords: Brown Algae, Cultivation, Fruit, Leaves, Seaweed, Weight.

\section{Pendahuluan}

Indonesia memiliki jenis rumput laut yang bernilai ekonomis, diantaranya adalah Sargassum sp. Sargassum sp. mengandung alginat dan iodine yang digunakan pada industri makanan, farmasi, kosmetik dan tekstil (Pakidi et al., 2016). Fajri, et al. (2020) menjelaskan bahwa Sargassum sp. tergolong jenis alga coklat (Phaeophyceae) yang tumbuh sepanjang tahun di perairan tropis, termasuk di Indonesia. Lingkungan tempat tumbuh Sargassum sp. banyak terdapat di daerah perairan yang jernih dengan substrat dasar karang, karang mati, dan batuan vulkanik yang berada di dasar perairan. Sargassum sp. tumbuh pada kedalaman kedalaman untuk pertumbuhan dari 0,5-10 m. Cokrowati et al., (2019) menjelaskan Sargassum aquifolium dapat tumbuh di perairan Pulau Lombok Nusa Tenggara Barat yaitu di perairan Teluk Ekas Lombok Timur, Batunampar Lombok Timur, Sekotong Lombok Barat, Senggigi Lombok Barat, dan Perairan Gerupuk
Lombok Tengah. Sargassum tumbuh sepanjang tahun di keseluruhan perairan tersebut. Secara ekologi Sargassum aquifolium merupakan tempat berlindung bagi telur dan anak ikan, udang, cumi dan benur. Sargassum aquifolium juga sebagai makanan alami bagi ikan herbivora serta biota laut lainnya yang bersifat herbivora.

Ketersediaan Sargassum sp. di alam terus dimanfaatkan yang akan mengakibatkan rumput laut cokelat ini semakin lama akan habis. Untuk itu perlu kesadaran untuk menjaga kelestarian Sargassum mengingat fungsi dan manfaat Sargassum sangat banyak. Usaha yang dilakukan untuk menjaga ketersediaan Sargassum di alam perlu dilakukan budidaya secara intensif dengan menggunakan metode Longline, Rakit apung, Patok Dasar maupun metode yang lain yang dapat membantu meningkatkan produksi rumput laut (Lutfiawan et al., 2015). Metode Longline yaitu metode pemeliharaan rumput laut yang dilakukan pada permukaan air dengan menggunakan tali sebagai media tanam. Metode longline mengandung keunggulan yakni 
fleksibel dalam pemilihan lokasi dan biaya yang dikeluarkan relatif lebih murah serta menjanjikan keuntungan yang lebih baik dibandingkan dengan metode lainnya (Aris et al., 2020).

Budidaya rumput laut ditentukan oleh musim dan kesesuaian lahan, selain itu ditentukan oleh metode budidaya yang digunakan (Bessie et al., 2018). Metode budidaya memiliki kontribusi yang signifikan terhadap hasil produksi dan kualitas rumput laut. Produksi Sargassum sp., yang maksimal dapat diperoleh dengan memperhatikan faktor pemilihan lokasi yang tepat, penggunaan bibit yang baik sesuai kriteria, jenis teknologi budidaya yang diterapkan, kontrol selama proses produksi, penanganan pasca panen rumput laut. Namun demikian, perbedaan biomassa memiliki pengaruh terhadap pertumbuhan rumput laut (Yusuf et al., 2017). Sementara itu, persaingan antar individu rumput laut dalam mendapatkan unsur hara memiliki kontribusi terhadap perbedaan biomassa (Budiyani et al., 2012). Bobot biomassa adalah salah satu faktor utama yang berpengaruh terhadap pertumbuhan rumput laut (Sarah et al., 2015).

Penelitian yang dilakukan oleh (Sulystyaningsih et al., 2019) dengan bobot antara $15 \mathrm{~g}, 25 \mathrm{~g}$, dan $35 \mathrm{~g}$ tidak dapat menghasilkan produksi yang maksimal. Sebaliknya, penelitian dengan bobot bibit yang lebih tinggi, peneliti ingin melihat respon pertumbuhan dari Sargassum sp. Budidaya dilakukan dengan bobot tanam yang lebih tinggi untuk mengetahui pertumbuhan Sargassum di Teluk Ekas Kabupaten Lombok Timur menggunakan metode longline. Tujuan penelitian ini adalah mempelajari pengaruh berat bibit yang berbeda terhadap Sargassum $s p$.

\section{Bahan dan Metode}

Penelitian ini dilaksanakan pada bulan Desember 2020 sampai dengan Januari 2021, di perairan Teluk Ekas Desa Ekas Buana, Kecamatan Jerowaru, Kabupaten Lombok Timur. Bahan dan alat yang digunakan adalah Sargassum aquifolium, tali rafia, tali nilon, tali jangkar, tiang pancang, jangkar, timbangan, meteran, kamera, tagging, termometer air, refraktometer, $\mathrm{pH}$ meter, oksigen meter, layanglayang arus dan stopwatch.

Penelitian ini dilakukan dengan menggunakan metode eksperimental dan menggunakan perlakuan perbedaan berat bibit Sargassum sp. Budidaya dilakukan selama 30 hari. Rancangan percobaan yang digunakan pada penelitian ini adalah Rancangan Acak Lengkap (RAL) yang terdiri atas 5 perlakuan serta masingmasing 4 kali ulangan. Perlakuan tersebut adalah Perlakuan A (bibit dengan berat 25 g), Perlakuan $\mathrm{B}$ (bibit dengan berat $50 \mathrm{~g}$ ), Perlakuan C (bibit dengan berat $100 \mathrm{~g}$ sebagai kontrol), Perlakuan D (bibit dengan berat $150 \mathrm{~g}$ ) dan Perlakuan E (bibit dengan berat $200 \mathrm{~g}$ ). Budidaya Sargassum sp. dilakukan sebagaimana pada Muslimin et al., (2016) dengan tahap pertama adalah persiapan konstruksi budidaya yaitu konstruksi longline dengan ukuran 10 meter x 5 meter. Tali ris sejumlah 20 dengan jarak antar tali ris $50 \mathrm{~cm}$. Tahap kedua adalah persiapan Bibit Sargassum sp, bibit yang digunakan diambil langsung dari perairan lokasi penelitian di Teluk Ekas, Kecamatan Jerowaru, Kabupaten Lombok Timur. Tahap ketiga adalah pengikat bibit Sargassum sp.pada tali ris yang telah disediakan. Tahap keempat adalah penanaman Sargassum sp. ke laut dan diikatkan pada tali pondasi longline. Tahap kelima adalah pengamatan pertumbuhan, dilakukan setiap 10 hari sekali. Pada penelitian ini, parameter yang menjadi objeks penelitian adalah:

\section{Pertumbuhan Mutlak}

Pertumbuhan Mutlak dapat dihitung dengan rumus Sahabati et al., (2016)

$$
\Delta W=W t-W o
$$

Keterangan:

$\Delta W$ : Pertumbuhan Mutlak (g)

$W t$ : Berat rata-rata rumput laut pada akhir percobaan $(\mathrm{g})$

$W o$ : Berat rata-rata rumput laut pada awal percobaan $(\mathrm{g})$

\section{Laju Pertumbuhan Spesifik}

Pengukuran laju pertumbuhan spesifik rumput laut menggunakan rumus sebagai berikut (Kasim et al., 2017)

$$
\mathrm{SGR}=\frac{\ln \mathrm{Wt}-\ln \mathrm{Wo}_{\mathrm{o}}}{t} \times 100 \%
$$

Keterangan:

SGR : Laju Pertumbuhan Spesifik (\% dalam berat basah per hari)

Wt : Berat bobot setelah sehari

Wo : Berat bobot awal 
t : Waktu dalam hari

\section{Perhitungan Jumlah Daun}

Pengamatan dilakukan dengan menghitung daun yang tumbuh selama rentan waktu 10 hari sekali untuk menganalisa pertumbuhan Sargassum sp.

\section{Perhitungan Jumlah Buah}

Jumlah buah Sargassum sp. dihitung setiap 10 hari sekali. Pengamatan dilakukan dengan menghitung buah yang tumbuh selama rentan waktu 10 hari untuk menganalisa pertumbuhan Sargassum sp.

\section{Hasil dan Pembahasan}

\section{Pertumbuhan Mutlak}

Pertumbuhan mutlak rumput laut yang tertinggi adalah perlakuan $\mathrm{E}$ (bibit dengan berat $200 \mathrm{~g}$ ) yaitu $437 \mathrm{~g}$. Pertumbuhan mutlak terendah pada perlakuan A (bibit dengan berat $25 \mathrm{~g}$ ) yaitu $250 \mathrm{~g}$. Berikut adalah grafik pertumbuhan mutlak pada semua perlakuan.

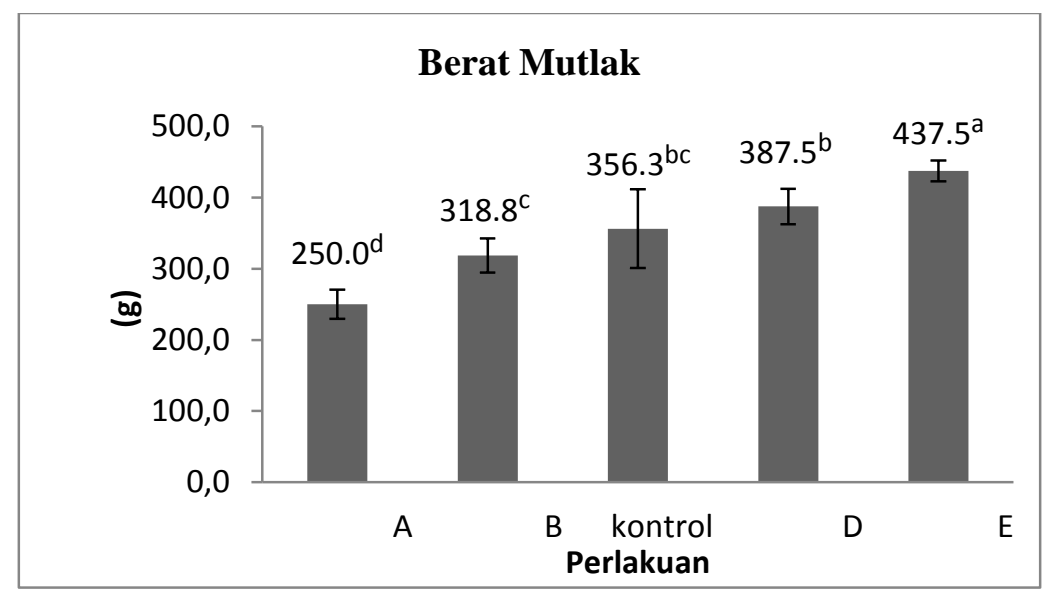

Gambar 1. Grafik Pertumbuhan Berat Mutlak Sargassum sp.

Hasil uji Duncan menunjukan berat perlakuan E $\left(437.5^{\mathrm{a}}\right)$ menunjukan hasil paling baik, berbeda nyata dengan berat bibit perlakuan A $\left(250.0^{\mathrm{d}}\right)$, bibit perlakuan B $\left(318.8^{\mathrm{c}}\right)$, berat bibit perlakuan C (kontrol) $\left(356.3^{\mathrm{bc}}\right)$, berat bibit perlakuan D $\left(387.5^{\mathrm{b}}\right)$, sedangkan perlakuan D dengan berat bibit $150 \mathrm{~g}$ tidak berbeda nyata dengan perlakuan $\mathrm{C}$ dengan berat bibit awal 100 g sebagai kontrol namun berbeda nyata dengan perlakuan B dengan berat bibit awal $50 \mathrm{~g}$ dan perlakuan A berat bibit awal $25 \mathrm{~g}$, dan perlakuan $\mathrm{C}$ dengan berat bibit $100 \mathrm{~g}$ (kontrol) tidak berbeda nyata dengan perlakuan B dengan berat bibit awal $50 \mathrm{~g}$ tetapi berbeda nyata dengan perlakuan A dengan berat bibit awal $25 \mathrm{~g}$. Pertumbuhan mutlak cenderung meningkat seiring dengan pertambahan berat bibit yang digunakan.

\section{Laju Pertumbuhan Spesifik}

Laju pertumbuhan spesifik (Sargassum sp.) yang diamati dari berat awal penanaman hingga minggu akhir penimbangan dalam penelitian dapat dilihat pada gambar berikut: 


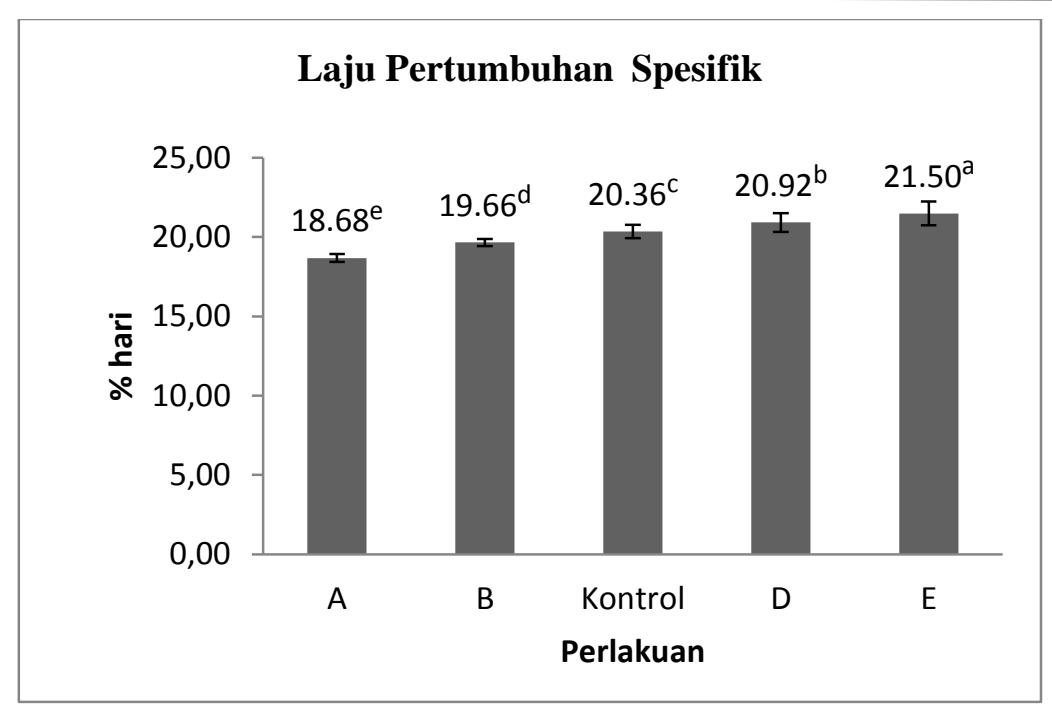

Gambar 2. Grafik laju pertumbuhan spesifik rumput laut

Hasil uji Duncan menunjukan laju pertumbuhan spesifik pada semua perlakuan terlihat berbeda nyata dengan nilai pada perlakuan A dengan nilai rata-rata $\left(18.68^{\mathrm{e}}\right)$, perlakuan B dengan nilai rata-rata $\left(19.66^{\mathrm{d}}\right)$, perlakuan $\mathrm{C}$ (kontrol) dengan nilai rata-rata $\left(20.36^{\mathrm{c}}\right)$, perlakuan $\mathrm{D}$ dengan nilai rata-rata $\left(20.92^{\mathrm{b}}\right)$, dan perlakuan $\mathrm{E}$ dengan nilai rata-rata $\left(21.50^{\mathrm{a}}\right)$. Laju pertumbuhan spesifik paling tinggi terdapat pada perlakuan $\mathrm{E}$ dengan nilai rata-rata 21,50\%/ hari, kemudian diikuti perlakuan D dengan nilai rata-rata $20,92 \% /$ hari, selanjutnya perlakuan C (Kontrol) dengan nilai 20,36\%/hari, perlakuan B $19,66 \% /$ hari, dan data yang paling rendah didapatkan pada perlakuan A dengan nilai rata-rata $18,68 \%$ /hari dalam sebulan masa pemeliharaan.

\section{Jumlah Buah}

Pertumbuhan buah rumput laut yang diamati dari awal pemeliharaan hingga minggu terakhir pemeliharaan dalam penelitian dapat dilihat pada gambar berikut:

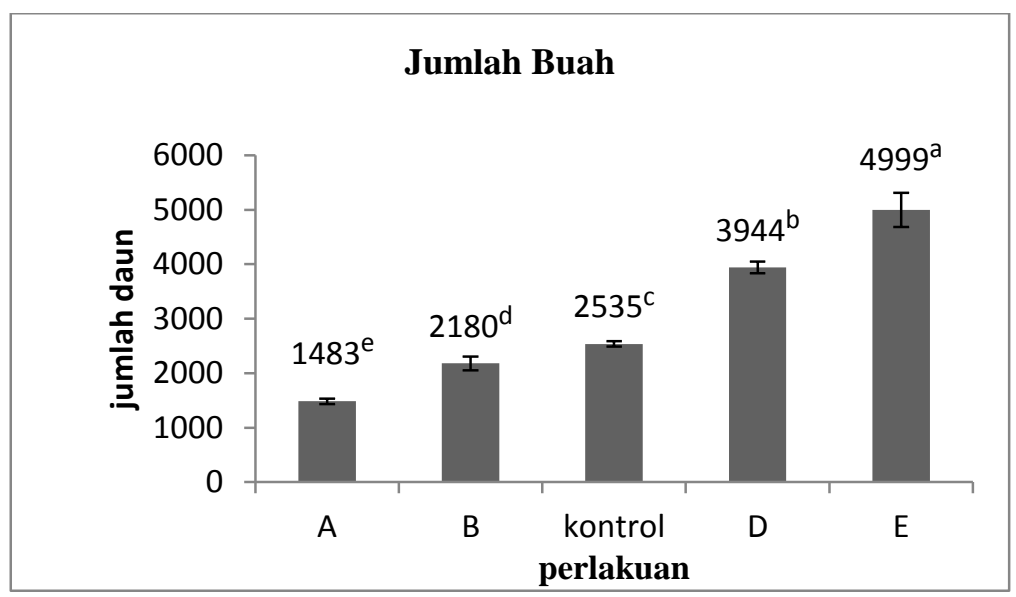

Gambar 3. Grafik Pertumbuhan Jumlah Buah (Sargassum sp.)

Pertumbuhan jumlah buah pada hasil uji Duncan terlihat berbeda nyata pada semua perlakuan. Perlakuan A dengan nilai rata-rata $\left(1483^{\mathrm{e}}\right)$, perlakuan $\mathrm{B}$ dengan nilai rata-rata $\left(2180^{\mathrm{d}}\right)$, perlakuan $\mathrm{C}$ (kontrol) dengan nilai rata- rata $\left(2535^{\mathrm{c}}\right)$, perlakuan $\mathrm{D}$ dengan nilai rata-rata $\left(3944^{b}\right)$, dan perlakuan $\mathrm{E}$ dengan nilai rata-rata $\left(4999^{\mathrm{a}}\right)$.

Pertumbuhan jumlah buah tertinggi terdapat pada perlakuan E dengan nilai rata-rata 
4999 buah, kemudian diikuti perlakuan D dengan nilai rata-rata 3944 buah, selanjutnya perlakuan $\mathrm{C}$ (kontrol) dengan jumlah nilai rata-rata 2535 buah, Perlakuan B dengan nilai rata-rata 2180 buah, dan data terendah didapatkan pada perlakuan A dengan jumlah 1483 buah dalam sabulan masa pemeliharaan.

\section{Jumlah Daun}

Pertumbuhan daun rumput laut yang diamati dari awal pemeliharaan hingga minggu terakhir pemeliharaan dalam penelitian dapat dilihat pada gambar berikut:

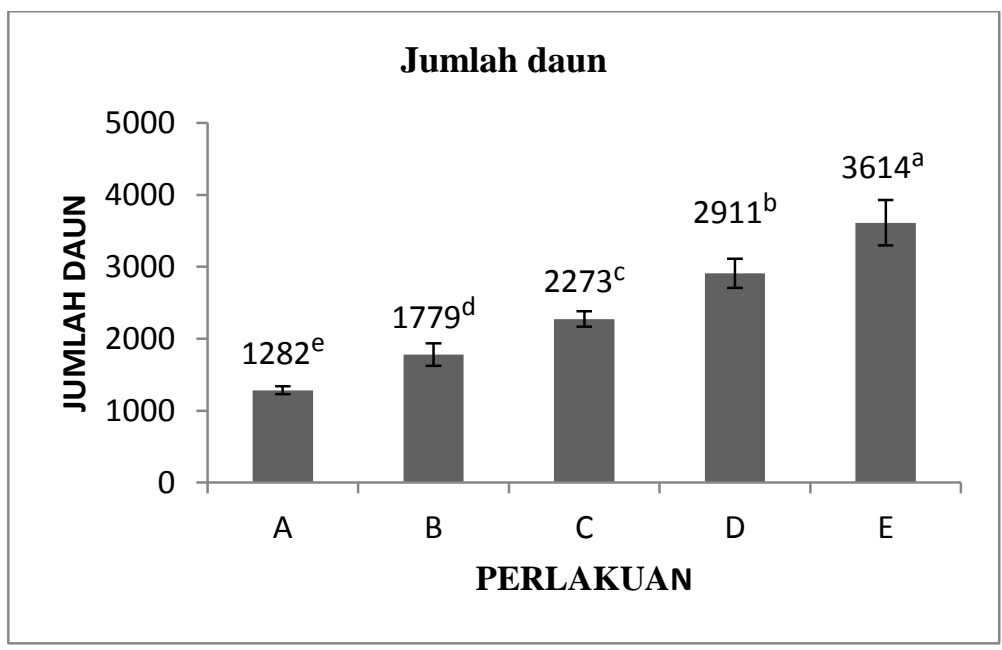

Gambar 4. Grafik Pertumbuhan Jumlah daun rumput laut

Pertumbuhan daun pada Hasil uji Duncan terlihat berbeda nyata pada semua perlakuan. Perlakuan A dengan nilai rata-rata $\left(1282^{\mathrm{e}}\right)$, perlakuan B dengan nilai rata-rata $\left(1779^{\mathrm{d}}\right)$, perlakuan $\mathrm{C}$ (kontrol) dengan nilai rata-rata $\left(2273^{c}\right)$, perlakuan D dengan nilai rata-rata $\left(2911^{\mathrm{b}}\right)$, perlakuan $\mathrm{E}$ dengan nilai rata-rata $\left(3614^{\mathrm{a}}\right)$. Pertumbuhan tertinggi terdapat pada perlakuan E dengan nilai rata-rata 3614 helai, kemudian diikuti perlakuan D dengan nilai ratarata 2911 helai, selanjutnya perlakuan C (kontrol) dengan jumlah nilai rata-rata 2273 helai, Perlakuan B dengan nilai rata-rata 1779 helai, dan data terendah didapatkan pada perlakuan A dengan jumlah 1282 buah dalam sabulan masa pemeliharaan.

\section{Kualitas Air}

Kualitas air yang didapatkan selama penelitian yang diukur setiap 10 hari satu kali adalah sebagai berikut:

Tabel 1. Kualitas air selama penelitian

\begin{tabular}{lll}
\hline Parameter & Nilai & Refrensi \\
\hline Suhu $\left({ }^{0} \mathrm{C}\right)$ & $27-32\left({ }^{0} \mathrm{C}\right)$ & $26-32(\mathrm{BSN}, 2011)$ \\
$\mathrm{DO}(\mathrm{ppm})$ & $5,1-7,4$ & $5-10 \mathrm{mg} / \mathrm{l}(\mathrm{C})$ rrowati et al., 2020$)$ \\
$\mathrm{pH}$ & $7,8-8,2$ & $7-8,5(\mathrm{BSN}, 2011)$ \\
Salinitas $(\mathrm{ppt})$ & $30-31$ & $28-34(\mathrm{BSN}, 2011)$ \\
Kecepatan Arus $(\mathrm{m} / \mathrm{s})$ & $1-6$ & $20-40($ Yusup, 2015) \\
Kecerahan $(\mathrm{m})$ & $1-4$ & $5 \mathrm{~m}($ Yusup, 2017) \\
Fosfat $(\mathrm{mg} / \mathrm{L})$ & $0,03-0,1$ & $>0,1(\mathrm{BSN}, 2011)$ \\
Nitrat $(\mathrm{mg} / \mathrm{L})$ & $10-12,5$ & $>0,04(\mathrm{BSN}, 2011)$ \\
\hline
\end{tabular}




\section{Pertumbuhan Mutlak}

Hasil budidaya yang dilakukan selama 30 hari dengan menggunakan 5 perlakuan untuk mengetahui pertumbuhan rumput laut Sargassum sp terbaik dengan berat bibit berbeda dan didapatkan hasil yang menunjukan bahwa berat bibit yang berbeda mempengaruhi pertumbuhan mutlak rumput laut Sargassum sp. Hasil ini ditunjukkan dengan analisis rata-rata pertumbuhan mutlak pada setiap perlakuan yaitu 250 g sampai dengan 437,5 g . Perbedaan berat bibit awal memberi pengaruh berbeda nyata (signifikan) terhadap pertumbuhan berat mutlak pada beberapa perlakuan yaitu $(\mathrm{P}<0.05)$. Perbedaan pertumbuhan berat mutlak Sargassum sp., diduga adanya unsur hara diperairan. Menurut (Rochmady, 2015), perbedaan pertumbuhan berat mutlak pada masing-masing perlakuan juga didukung oleh adanya unsur hara yang cukup diperairan untuk menunjang rumput laut. Penelitian Kotta (2020) juga menjelaskan hasil penelitiannya bahwa berat bibit yang berbeda juga menghasilkan pertumbuhan yang berbeda.

Tingginya nilai pertumbuhan berat mutlak pada perlakuan E berat bibit $200 \mathrm{~g}$, diduga karena banyak thallus (percabangan) sehingga memiliki permukaan yang luas untuk menyerap nutrisi yang ada di perairan. Sehingga penyerapan unsur hara (nutrient) dapat mempercepat pertumbuhan percabangan. Selain itu, tingginya pertumbuhan Sargassum ini diduga disebabkan oleh masa tanam pada musim penghujan Menurut (Muslimin et al., 2016), biomassa terbesar dan panjang thallus maksimal Sargassum sp. biasanya lebih baik pertumbuhannya pada musim hujan, sedangkan pada musim kemarau pertumbuhannya akan mengalami penurunan dengan hanya meninggalkan substrat dasarnya saja.

Faktor yang mempengaruhi pertumbuhan rumput laut adalah intensitas cahaya. Cahaya dibutuhkan oleh rumput laut dalam melakukan proses fotosintesis. Pada umumnya, cahaya yang digunakan untuk membantu proses fotosintesis adalah cahaya matahari. Menurut Runtuboy et al., (2018), pertumbuhan dan reproduksi rumput laut berhubungan erat dengan proses fotosintesis. Proses fotosintesis jauh lebih cepat terjadi pada intensitas cahaya yang tinggi dari pada ketika tumbuh pada intensitas cahaya yang rendah.

\section{Laju Pertumbuhan Spesifik}

Hasil penelitian menunjukan bahwa berat bibit yang berbeda mempengaruhi laju pertumbuhan spesifik rumput laut Sargassum $s p$. Hasil ini dibuktikan dengan analisis rata-rata laju pertumbuhan spesifik pada setiap perlakuan. Menurut (Rochmady, 2015), selain perbedaan berat bibit awal, juga karena adanya kecukupan unsur hara dalam perairan serta akibat dari faktor fisik perairan berupa suhu dan intensitas cahaya matahari.

Pada setiap waktu penimbangan, rumput laut mengalami peningkatan pertumbuhan dan rumput laut mengalami laju pertumbuhan tertinggi pada minggu ke-2 setelah penanaman bibit. Menurut Sapitri et al., (2016) rumput laut baik dipanen pada umur 30 hari (lebih awal). Hal ini karena rumput laut masih mengalami pertumbuhan yang bagus pada umur \pm 30 hari dan tidak mampu mempertahankan thallus yang berat setelah melewati umur 30 hari.

Laju pertumbuhan spesifik rumput laut dapat dipengaruhi oleh faktor kualitas bibit. Bibit yang berkualitas akan sangat menunjang pertumbuhan rumput laut yang dibudidayakan, selain faktor bibit, unsur hara diperairan dan kualitas air juga memiliki peran yang penting dalam pertumbuhan rumput laut. Menurut Lutfiawan et al., (2015) menyatakan bahwa adanya zat hara dari kadar nitrat dan fosfat dapat berpengaruh terhadap reproduksi alga bila zat hara tersebut melimpah.

\section{Jumlah Buah}

Hasil penelitian menunjukan bahwa pertumbuhan rumput laut Sargassum $s p$. dapat dilihat dari pertumbuhan jumlah buah setiap 10 hari. Hasil ini dibuktikan dengan analisis ratarata pertumbuhan jumlah buah pada setiap perlakuan. Pertumbuhan paling tinggi terdapat pada perlakuan E dengan jumlah buah 4999, tingginya pertambahan jumlah buah pada perlakuan E didukung oleh terpenuhinya unsur hara.

Dari hasil analisis ragam (ANOVA) menunjukan bahwa perbedaan berat awal bibit rumput laut juga mempengaruhi pertumbuhan buah yang (signifikan) $(\mathrm{P}<0.05)$. Adanya perbedaan pertumbuhan buah Sargassum sp., diduga dipengaruhi oleh unsur hara yang didapatkan di perairan serta kondisi lingkungan dan cuaca yang kurang baik seperti gelombang 
tinggi menyebabkan rumput laut satu dengan yang lain terbawa arus dan berkumpul menjadi satu. Hal ini menyebabkan terjadinya persaingan untuk mendapatkan nutrient. Menurut Novianti et al. (2015) menyatakan bahwa unsur nitrogen (N) merupakan unsur makro yang bermanfaat untuk memacu pertumbuhan, karena nitrogen diperlukan oleh tumbuhan untuk melakukan proses fotosintesa dan komponen penting dalam protoplasma. Menurut (Lutfiawan et al., 2015) menyatakan bahwa, buah Sargassum tumbuh pada tiap percabangan yang berbentuk bulat, buah Sargassum berfungsi untuk menopang cabang-cabang Thallus terapung kearah permukaan air untuk mendapatkan intensitas cahaya matahari.

Putra et al., (2012) juga menyatakan bahwa, faktor eksternal seperti keadaan lingkungan fisik dan kimiawi perairan yang dapat menghambat pertumbuhan rumput laut. Faktor fisik seperti suhu, salinitas, $\mathrm{pH}$ dan unsur $\mathrm{N}$ dan $\mathrm{P}$ termasuk unsur kimiawi yang ada diperairan yang mendukung pertumbuhan rumput laut.

\section{Jumlah Daun}

Hasil penelitian menunjukan bahwa pertumbuhan rumput laut Sargassum $s p$. dapat dilihat dari pertumbuhan jumlah daun setiap 10 hari. Pertumbuhan terbaik pada perlakuan E dengan jumlah daun 3614 helai. Hasil ini dibuktikan dengan analisis rata-rata pertumbuhan jumlah daun pada setiap perlakuan. Hal ini dapat dilihat pada hasil uji ANOVA.

Pertumbuhan jumlah daun jika dilihat dari hasil uji Duncan setiap perlakuan menunjukkan hasil yang sangat berbeda nyata $(\mathrm{P}<0.05)$. Hal ini diduga karena adanya penumpukan rumput laut akibat terbawa arus sehingga pertumbuhan rumput laut yang tertimbun kurang optimal. Selain itu, adanya kotoran yang menempel pada rumput laut menjadi salah satu faktor Sargassum $s p$. kurang mendapatkan unsur hara. Menurut Hermawan (2015) menyatakan bahwa kotoran yang menempel pada rumput laut menyebabkan memudarnya pigmentasi sehingga menyebabkan rumput laut mudah patah, menghambat pertumbuhan dan akhirnya mati.

\section{Kualitas Air}

Hasil pengukuran suhu berkisar antara 27$30.7^{\circ} \mathrm{C}$. Kisaran suhu tersebut sesuai dengan syarat budidaya rumput laut. Hal ini sesuai dengan pernyataan Yudasmara (2014) yang menyatakan bahwa suhu yang baik untuk rumput laut adalah $27,5^{\circ} \mathrm{C}$. Tinggi rendahnya suhu perairan dipengaruhi oleh penetrasi cahaya yang masuk kedalam perairan. Sedangkan nilai kandungan oksigen (DO) dalam perairan Teluk Ekas berkisar antara 5.1-5.5 ppm. Menurut Arjuni et al. (2018) menyatakan bahwa baku mutu oksigen terlarut untuk rumput laut adalah lebih dari $5 \mathrm{mg} / \mathrm{l}$, hal ini berarti jika oksigen terlarut dalam perairan mencapai $5 \mathrm{mg} / \mathrm{l}$ maka metabolism rumput laut dapat berjalan dengan optimal. Rumput laut membutuhkan oksigen $\left(\mathrm{O}_{2}\right)$ ketika kondisi tidak ada intensitas cahaya yang cukup.

Hasil pengukuran derajat keasaman atau pH yang dilakukan di perairan Teluk Ekas didapatkan hasil berkisar anatara 7,8-8,2. Kisaran $\mathrm{pH}$ sesuai dengan kebutuhan rumput laut. Menurut Arjuni et al., (2018) menyatakan bahwa hamper seluruh alga menyukai kisaran $\mathrm{pH}$ 6.8-9.6. Sedangkan nilai salinitas di perairan Teluk Ekas yang didapatkan berkisar anatara 3032 ppt. Salinitas tersebut sudah sangat baik untuk pertumbuhan rumput laut, hal ini sesuai dengan pernyataan dari BSN (2011), nilai salinitas untuk menunjang pertumbuhan rumput laut berkisar anatara 28-34 ppt.

Kecepatan arus didapatkan di lokasi penelitian berkisar antara 1-6 cm/s. Kecepatan arus memiliki peranan penting dalam membawa nutrisi yang dibutuhkan untuk pertumbuhan rumput laut dan suplai oksigen di perairan. Kisaran tersebut masih cukup baik dalam budidaya rumput laut, sesuai dengan pernyataan Novianti et al,. (2015) bahwa kisaran yang baik untuk budidaya rumput laut sebesar $20-40 \mathrm{~cm} / \mathrm{s}$. Sedangkan nilai kecerahan pada lokasi penelitian didapatkan berkisar antara 1-4 m kecerahan dilokasi sangat dipengaruhi oleh pasang surut dan intensitas cahaya yang masuk ke dasar perairan.

Fosfat dan nitrat adalah nutrient penentu kesuburan di suatu perairan. Kadar fosfat yang didapatkan pada sampel air Teluk Ekas adalah berkisar antara $0.03 \mathrm{mg} / \mathrm{L}-0.1 \mathrm{mg} / \mathrm{L}$. Kadar Nitrat yaitu 10-12.5 mg/L. dengan kandungan nitrat yang tergolong tinggi menyebabkan pertumbuhan rumput laut dapat optimal dalam pertumbuhannya. Menurut BSN (2011), kadar fosfat dan nitrat di perairan yang baik untuk 
budidaya rumput laut yaitu $>0.1$ dan $>0.04$ $\mathrm{mg} / \mathrm{L}$.

\section{Kesimpulan}

Berdasarkan hasil dari penelitian ini, dapat disimpulkan bahwa berat bibit yang berbeda memberikan pengaruh yang nyata terhadap pertumbuhan rumput laut Sargassum sp. Berat bibit pada penelitian ini yang menghasilkan pertumbuhan terbaik adalah $200 \mathrm{~g}$ yang menghasilkan pertumbuhan mutlak $437.5 \mathrm{~g}$, laju pertumbuhan spesifik 21.50\%, jumlah buah 4999 buah, dan jumlah daun 3614 helai.

\section{Ucapan Terima Kasih}

Ucapan terima kasih disampaikan kepada pembudidaya rumput laut di perairan Teluk Ekas Desa Ekas Buana Kabupaten Lombok Timur yang telah membantu terlaksananya penelitian ini.

\section{Referensi}

Arjuni, A., Nunik, C., \& Rusman. (2018). Pertumbuhan Rumput Laut Kappaphycus alvarezii Hasil Kultur Jaringan. Jurnal Biologi Tropis. Volume 18 No:2. Program Studi Pendidikan Biologi. FKIP Universitas Mataram. UPT Mataram University Press.

DOI: http://dx.doi.org/10.29303/jbt.v18i2. 740 .

Badan Standar Nasional (BSN). (2011). Produksi Bibit Rumput Laut Kotoni (Eucheuma cottoni). Bagian 1 : Metode Lepas Dasar. Jakarta.

Budiyani, F.B., Suwartimah, K., \& Sunaryo. (2012). Pengaruh Penambahan Nitrogen dengan Konsentrasi yang Berbeda terhadap Laju Pertumbuhan Rumput Laut Caulerpa racemosa var. uvifera. Journal of Marine Research. 1 (1): 10-18. http://ejournal-

s1.undip.ac.id/index.php/jmr.

Bessie, D.M., Umbu P. \& L. Dawa. (2018). Analisis Kesesuaian Lahan Budidaya Rumput Laut di Desa Parumaan. Jurnal
Patner. 23 (1).

DOI:http://dx.doi.org/10.35726/jp.v23i1.2 97.

Aris, M. (2020). Laju transmisi penyakit ice-ice pada rumput laut Kappaphycus alvarezii berdasarkan jarak tanam dengan metode longline. Budidaya Perairan. 8 (2). 82-90. DOI:https://doi.org/10.35800/bdp.8.2.202 0.30057 .

Cokrowati, N., \& Nanda, D. (2019). Komponen Sargassum aquifolium sebagai hormon pemicu tumbuh untuk Eucheuma cottonii. Jurnal Biologi Tropis.19 (2): 316 - 321. DOI: 10.29303/jbt.v19i2.1107.

Cokrowati, N., Nanda, D., Dewi, N.S., \& Alis, M. (2020). Pertumbuhan Rumput Laut Hasil Kultur Jaringan Kappaphcus alvarezii. Jurnal of Fisheries and Marine Research. 4 (1) : 62-65. DOI: http://dx.doi.org/10.21776/ub.jfmr.2 020.004.01.9.

Fajri, I. M., Samidjan, D. \& Rachmawati. (2020). Pengaruh Jarak Tanam Rumput Laut (Sargassum sp.) yang Berbeda Terhadap Pertumbuhan. Sains Akuakultur Tropis: Indonesian Journal of Tropical Aquaculture. 4 (2). PP. 156-160. https://doi.org/10.14710/sat.v4i2.6920.

Hermawan, D. (2015). Pengaruh Perbedaan Strain Rumput Laut Kappaphycus alvarezii Terhadap Laju Pertumbuhan Spesifik. Jurnal Perikanan dan Kelautan. 5 (1). 71-78.

file:///C:/Users/asus/Downloads/281-4891-SM.pdf

Kasim, M., \& Ahmad, M. (2017). Comparison Growth Of Kappaphycus Alvarezii (Rhodophyta, Solieriaceae) Cultivation In Floating Cage And Longline In Indonesia. Jurnal Aquaculture Reports. 6 : 49-55. https://doi.org/10.1016/j.aqrep.2017.03.0 04.

Kotta. R. (2020). Pertumbuhan Rumput Laut Kappaphycus alvarezi Menggunakan Metode Budidaya Long Line Pada 
Kedalaman Berbeda Terhadap Peningkatan Berat Bibit : Kajian Pustaka. Jurnal Ilmu Kelautan Kepualauan. 3 (1): 46-58.

DOI: http://dx.doi.org/10.33387/jikk.v3i1. 1860

Lutfiawan, M., \& Karnan, L. J. (2015). Analisis Pertumbuhan Sargassum sp. Dengan Sistem Budidaya Yang Berbeda Di Teluk Ekas Lombok Timur Sebagai Bahan Pengayaan Mata Kuliah Ekologi Tumbuhan. Jurnal Biologi Tropis. 15(2) : 129-138.

DOI: http://dx.doi.org/10.29303/jbt.v15i2 .157

Muslimin \& Wiwin, K.P.S. (2017). Budidaya Rumput Laut Sargassum sp. Dengan Metode Kantong Pada Beberapa Tingkat Kedalaman di Dua Wilayah Perairan Berbeda. Jurnal Riset Akuakultur. 12(3) 221-230.

DOI: http://dx.doi.org/10.15578/jra.12.3.2 017.221-230.

Muslimin \& Wiwin, K.P.S. (2016). Petunjuk Teknis Teknologi Budidaya Sargassum sp. dengan Menggunakan Metode Lepas Dasar. Loka Riset Budidaya Rumput Laut. Gorontalo. https://kkp.go.id/ancomponent/media/upload-gambarpendukung/LOKA\%20RISET\%20BUDI DAYA\%20RUMPUT\%20LAUT/JUKNI S\%20SARGASSM\%202016.pdf.

Novianti, D.N., S. Rejeki, \& T. Susilowati. (2015). Pengaruh Bobot Awal Yang Berbeda Terhadap Pertumbuhan Rumput Laut Latoh (Caulerpa lentillifera) yang Dibudidayakan Didasar Tambak, Jepara. Jurnal of Aquaculture Management and Technology. $\quad 4(4): \quad 67-73$. https://ejournal3.undip.ac.id/index.php/ja $\mathrm{mt} /$ article/view/10048.

Pakidi, C. S. \& Musamus, U. (2016). Potensi dan Pemanfaatan Bahan Aktif Alga Cokelat Sargassum sp. Jurnal Octopus. 5 (2), Juni 2016. https://core.ac.uk/download/pdf/2336013 71.pdf.
Putra, N.S.S.U., Jumriadi., Michael. R., \& Sugeng, R. (2012). Budidaya Lawi-Lawi (Caulerpa sp.) Di Tambak Sebagai Upaya Diversifikasi Budidaya Perikanan. Indonesia Aquacultur dan Forum Inovasi Teknologi Aquacultur.

https://www.slideshare.net/putranana/budi daya-lawi-lawi-caulerpa-sp-di-tambak.

Sarah Nur Iskandar, \& Sri Rejeki, T. S. (2015). Pengaruh Bobot Awal Yang Berbeda Terhadap Pertumbuhan Caulerpa lentillifera yang Dibudidayakan Dengan Metode Longline Ditambak Bandengan Jepara. Journal of aquaculture Management and Technology. 4(4) : 2127.

https://ejournal3.undip.ac.id/index.php/ja $\mathrm{mt} /$ article/view/9800

Sahabati, S., Joppy, D. M., \& Lukas L.J.J.M. (2016). Pertumbuhan Rumput Laut (Kappaphycus alvarezii) Yang di Budidayakan Dalam Kantong Jaring Dengan Berat Awal Berbeda di Teluk Talengen Kepulauan Sangihe. Jurnal Budidaya Perairan. 4(3): 16-21. https://ejournal.unsrat.ac.id/index.php/bd p/article/view/14742/14311

Sapitri, A.R., Cokrowati, N., \& Rusman. (2016). Pertumbuhan Rumput Laut Kappaphycus alvarezii Hasil Kultur Jaringan Pada Jarak Tanam Berbeda. Jurnal Depik. 5(1). : 1218.

DOI: http://dx.doi.org/10.13170/depik.5.1.3843

Rochmady, Sulaeman, \& La Salauddin. (2017). Pengaruh Bobot Bibit Berbeda Terhadap Pertumbuhan Rumput Laut (Kappaphycus alvarezii) Strain Cokelat Metode Long Line Menggunakan Rumpun Ganda. Agrikan: Jurnal Agribisnis Perikanan. 8 (2), Oktober 2015, Pages 1-7. https://doi.org/10.29239/j.agrikan.8.2.1-7

Runtuboy, N., \& Slamet, A. (2018). Pengaruh Kedalaman Tergadap Perkembangan Rumput Laut Kotoni Hasil Kultur Jaringan. Jurnal Penyuluhan Perikanan 
dan Kelautan. 12 (3): 196-206. DOI: org/10.33378/jppik.v12i3.110.

Sahabati, S., Joppy, D. M., \& Lukas L.J.J.M. (2016). Pertumbuhan Rumput Laut (Kappaphycus alvarezii) yang di Budidayakan Dalam Kantong Jaring Dengan Berat Awal Berbeda di Teluk Talengen Kepulauan Sangihe. Jurnal Budidaya Perairan. 4(3): 16-21. DOI: https://doi.org/10.35800/bdp.3.1.20 15.6929

Sarah Nur Iskandar, \& Sri Rejeki, T. S. (2015). Pengaruh Bobot Awal Yang Berbeda Terhadap Pertumbuhan Caulerpa lentillifera Yang Dibudidayakan Dengan Metode Longline Ditambak Bandengan Jepara. Journal of aquaculture Management and Technology. 4(4) : 2127.

https://ejournal3.undip.ac.id/index.php/ja $\mathrm{mt} /$ article/view/9800.

Sulystyani, N. D., Rajuddin, S., \& Zainuddin (2019). Pengaruh Kedalaman dan Bobot
Sargassum aquifolium Terhadap Tingkat Serangan Ice-Ice dan Kadar Keragenan Pada Rumput Laut Kappaphycus alvarezii. Jurnal Riset Akuakultur. 14 (1) : 39-46.

DOI: http://dx.doi.org/10.15578/jra.14.1.2 019.39-46

Yudasmara, G.A. (2014). Budidaya Anggur Laut (Caulerpa racemosa) Melalui Media Tanam Rigid Quadrant Nets Berbahan Bambu. Jurnal Sains dan Tekhnologi. 3(2). DOI: http://dx.doi.org/10.23887/jstundiksha.v3i2.4481

Yusup, S., Ma'ruf, K., \& Abdul, M, B. (2017). Pengaruh Bobot Awal Yang Berbeda Terhadap Pertumbuhan Dan Kandungan Keragenan Rumput Laut Kappaphycus alvarezii Yang Terserang Epifit dalam Rakit Jaring Apung. Jurnal Media Akuatika. 2(4) : 509-518. DOI: http://dx.doi.org/10.33772/jma.v2i4. 4356. 